\title{
Efficient Methodology for Selective Alkylation of Hydrazine Derivatives
}

\author{
Aleksei Bredihhin, ${ }^{\dagger}$ Ulrich M. Groth, ${ }^{\ddagger}$ and Uno Mảeorg ${ }^{*}, \dagger$ \\ Institute of Organic and Bioorganic Chemistry, University of Tartu, \\ Jakobi 2, 51014 Tartu, Estonia, and Department of Chemistry, \\ University of Konstanz, Konstanz D-78464, Germany \\ uno@chem.ut.ee
}

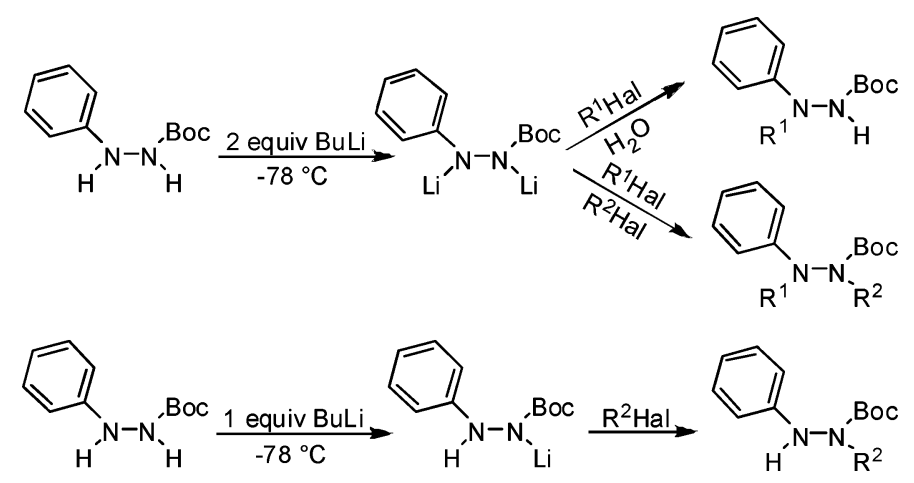

Formation and use of a nitrogen dianion for selective hydrazine alkylation is reported. The scope and limitations of a new method were demonstrated. The novel method provides fast and easy access to substituted hydrazines, which are widely used as drugs, pesticides, and precursors for a variety of compounds in organic synthesis.

Many hydrazine derivatives show remarkable biological activities. Hydrazine derivatives are well-known among pesticides, drugs, amino acid precursors, and synthetic building blocks for heterocycle synthesis. Several similar compounds were shown to be effective for treatment of tuberculosis, Parkinson's disease, and hypertension. ${ }^{1}$ Also, hydrazine-based peptidomimetics (azapeptides) are found to be potent agents against diseases such as hepatitis, AIDS, and SARS. ${ }^{2}$ Therefore, it can be easily seen that synthesis of substituted hydrazines is a matter of great interest.

A number of systematic synthetic methods using orthogonal protective group methodology were recently developed. ${ }^{3}$

\footnotetext{
University of Tartu.

$\doteqdot$ University of Konstanz.

(1) For a review, see: Ragnarsson, U. Chem. Soc. Rev. 2001, 30, 205220 .

(2) (a) Zhang, R.; Durkin, J. P.; Windsor, W. T. Bioorg. Med. Chem. Lett. 2002, 12, 1005-1008. (b) Lee, T.-W.; Cherney, M. M.; Huitema, C.; Liu, J.; James, K. E.; Powers, J. C.; Eltis, L. D.; James, M. N. G. J. Mol. Biol. 2005, 354, 1137-1151.
}

These methods have their specific advantages but demand many steps (protection and deprotection) for obtaining the end product. Very recently, several methods using only two protective groups have been reported. ${ }^{4}$ Our method we wish to report here provides hydrazine derivatives with a minimum number of steps and protective groups.

Metalation of the $\mathrm{NH}$ group followed by addition of an electrophile is widely used in amine alkylation. However, in hydrazine alkylation, there are several problems such as

(3) (a) Mäeorg, U.; Grehn, L.; Ragnarsson, U. Angew. Chem., Int. Ed. Engl. 1996, 35, 2626-2627. (b) Mäeorg, U.; Ragnarsson, U. Tetrahedron Lett. 1998, 39, 681-684. (c) Mäeorg, U.; Pehk, T.; Ragnarsson, U. Acta Chem. Scand. 1999, 53, 1127-1133. (d) Grehn, L.; Löhn, H.; Ragnarsson, U. Chem. Commun. 1997, 1-2. (e) Brosse, N.; Pinto, M.-F.; JamartGregoire, B. J. Org. Chem. 2000, 65, 4370-4374. (f) Brosse, N.; Pinto, M.-F.; Bodiguel, J.; Jamart-Gregoire, B. J. Org. Chem. 2001, 66, 28692873.

(4) (a) Tsubrik, O.; Mäeorg, U. Org. Lett. 2001, 3, 2297-2299. (b) Tsubrik, O.; Mäeorg, U.; Ragnarsson, U. Tetrahedron Lett. 2002, 43, 62136215. (c) Tsubrik, O.; Mäeorg, U.; Sillard, R.; Ragnarsson, U. Tetrahedron 2004, 60, 8363-8373. 
selectivity, lability of protective groups, etc. ${ }^{5}$ Despite all aforementioned concerns about stability of such kinds of compounds, a dianion, formed by metalation of PhNHNHBoc, was very stable in solution even at room temperature. Also, one might expect problems with solubility; however, this dianion is very soluble in THF. In strong contrast to the THF solution of the monoanion, which is mostly of red color, the THF solution of the dianion exhibits a clear bright yellow color. Therefore, this can be used for titration of strong bases.

Familiarity with the acidity of $\mathrm{NH}$ groups is of vital interest for the preparative chemist. Knowledge of corresponding $\mathrm{p} K_{\mathrm{a}}$ values can be useful in the prediction of reactivity of compounds, thus providing the way to selective reactions. Recent reports show great advances in structure-property relationship development using NH group acidity. $\mathrm{p} K_{\mathrm{a}}$ values of corresponding $\mathrm{NH}$ groups can be estimated as 28 $\left(\mathrm{PhNHNH}_{2}\right)$ and $17(\mathrm{PhNHNHCbz}){ }^{6}$ This huge difference provides an opportunity for selective alkylation of either the $\mathrm{PhNH}$ or the BocNH group.

Our method can be used in several different ways. It is possible to perform double (symmetrical) alkylation, selective monoalkylation of either of the nitrogens, or one-pot selective alkylation of both nitrogens with different substituents.

There are very few reports utilizing a similar methodology for the preparation of pyrazolidine ring systems, but there are no reports about selective alkylation. ${ }^{7}$ Furthermore, our method provides the possibility to carry out reactions under milder conditions, more safely and with simpler separation of products with an excellent yield.

We have started with symmetrical alkylation (Scheme 1). $\mathrm{PhNHNHBoc}$ can be easily prepared from phenyl hydrazine

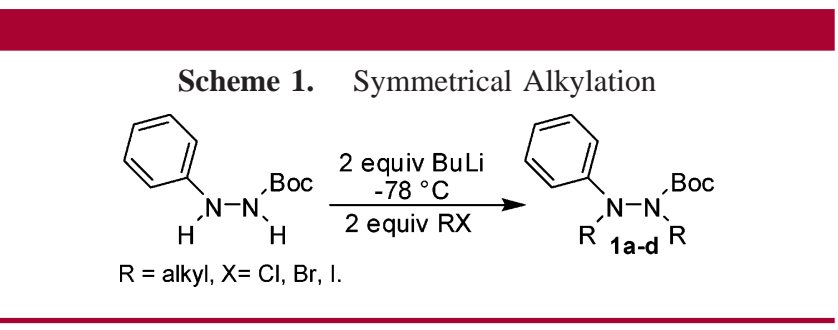

and $\mathrm{Boc}_{2} \mathrm{O} .^{3}$ Metalation was conducted in THF at $-78{ }^{\circ} \mathrm{C}$ with 2 equiv of $n$-BuLi. Dianion formation was detected via color change of the solution. The alkylating agent was then added at room temperature. Alkylation took from $3 \mathrm{~h}$ to 4 days depending on the bulkiness of the employed electrophile and its reactivity. The reaction rate increases in the following order of leaving groups: chloride, bromide, and iodide. Bulkier alkyl halogenides also exhibit a lower rate of reaction. Reactions were monitored by TLC, and the stepwise character of reactions could easily be observed; i.e., monoalkylated products were formed quickly $(2 \mathrm{~h})$, and dialkylated products were formed very slowly (1-4 days). The reaction

(5) (a) Brown, B. R. The Organic Chemistry of Aliphatic Nitrogen Compounds; Clarendon: Oxford, United Kingdom, 1994; pp 588. (b) Greene, T. W.; Wuts, P. G. M. Protective Groups in Organic Synthesis, 3rd ed.; John Wiley \& Sons, Inc.: New York, 1999; Chapter 10, pp 737. proceeded without the formation of byproducts. It was not possible to obtain dialkylated product from sterically more hindered electrophiles ( $\operatorname{Pr}, i$-Pr, etc.) even using a great excess of alkylating agent.

An attempt to utilize dielectrophiles was successful (2h). Therefore, this method opens the access to many heterocycles (pyrazolidine, piperazine, etc.) in a simple and convenient one-pot fashion.

Because the first alkylation of the dianion proceeded much faster, selective monoalkylation at the more reactive phenyl nitrogen (Scheme 2) was conducted under conditions similar

Scheme 2. Selective Alkylation of Phenyl Nitrogen

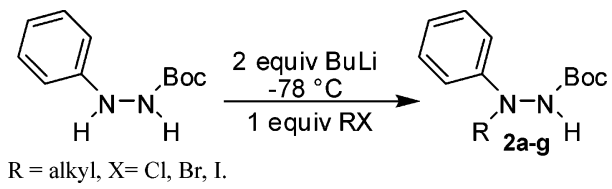

to those for the dialkylation, with the only exception being the addition of only 1 equiv of alkyl halide. Reactions were normally complete within 2 h. For the reactive electrophiles (methyl, allyl, etc.), traces of unselective alkylation products were observed. This problem could be overcome by addition of the alkylating agent at lower temperature.

Monoalkylation of the Boc nitrogen (Scheme 3) was more complicated. Alkylation was carried out at $-20{ }^{\circ} \mathrm{C}$ because

Scheme 3. Selective Alkylation of Boc Nitrogen

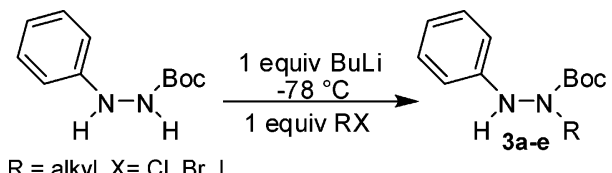

$\mathrm{R}=\operatorname{alkyl}, \mathrm{X}=\mathrm{Cl}, \mathrm{Br}, \mathrm{l}$.

at higher temperatures alkylation proceeded unselectively, probably due to some kind of equilibrium between monometallated intermediates. This type of reaction is much slower than those described above.

Successful consecutive monoalkylation of both nitrogens with diverse electrophiles in a one-pot fashion could also be achieved (Scheme 4). Probably this method is the most

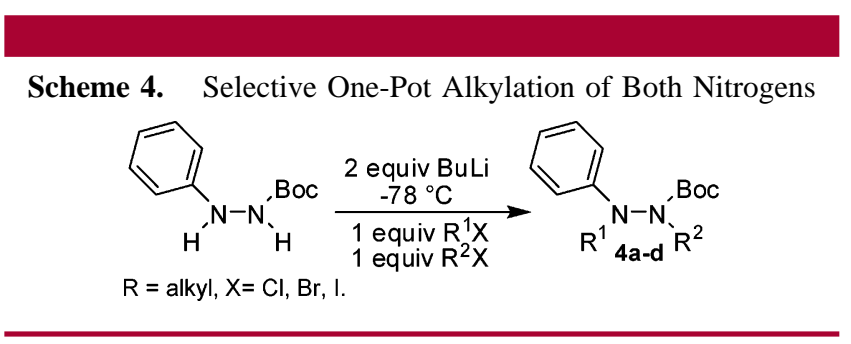

interesting of the methods described here from the practical point of view. 
Table 1. Alkylation Products

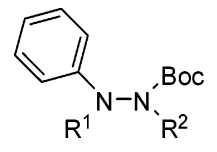

\begin{tabular}{|c|c|c|c|c|}
\hline & $\mathrm{R}^{1}$ & $\mathrm{R}^{2}$ & conditions & yield, \% \\
\hline $\mathbf{1 a}$ & $\mathrm{Me}$ & $\mathrm{Me}$ & 2 equiv of $\mathrm{MeI}, 3 \mathrm{~h}, \mathrm{rt}$ & 89 \\
\hline $1 \mathbf{b}$ & Et & Et & 2 equiv of $\mathrm{EtBr}, 4$ days, $\mathrm{rt}$ & 87 \\
\hline 1c & All & All & 2 equiv of AllBr, 1 day, rt & 85 \\
\hline 1d & $\mathrm{Bz}$ & $\mathrm{Bz}$ & 2 equiv of $\mathrm{BzBr}, 1$ day, $\mathrm{rt}$ & 92 \\
\hline $\mathbf{2 a}$ & $\mathrm{Me}$ & $\mathrm{H}$ & $\mathrm{MeI}, 2 \mathrm{~h}, \mathrm{rt}$ & 86 \\
\hline $\mathbf{2 b}$ & Et & $\mathrm{H}$ & $\mathrm{EtBr}, 2 \mathrm{~h}, \mathrm{rt}$ & 82 \\
\hline $2 c$ & $n-\operatorname{Pr}$ & $\mathrm{H}$ & $\mathrm{PrBr}, 2 \mathrm{~h}, \mathrm{rt}$ & 80 \\
\hline 2d & $i-\operatorname{Pr}$ & $\mathrm{H}$ & $i$-PrI, $2 \mathrm{~h}, \mathrm{rt}$ & 76 \\
\hline $2 \mathbf{e}$ & All & $\mathrm{H}$ & AllBr, 2 h, rt & 90 \\
\hline $2 f$ & $\mathrm{Bz}$ & $\mathrm{H}$ & $\mathrm{BzBr}, 2 \mathrm{~h}, \mathrm{rt}$ & 76 \\
\hline $2 \mathrm{~g}$ & $\mathrm{C}_{7} \mathrm{H}_{13}{ }^{a}$ & $\mathrm{H}$ & $\mathrm{C}_{7} \mathrm{H}_{13} \mathrm{Br}, 2 \mathrm{~h}, \mathrm{rt}$ & 78 \\
\hline $\mathbf{2 h}$ & $-\left(\mathrm{CH}_{2}\right)_{3}-$ & $\mathrm{H}$ & IPrI, $1 \mathrm{~h}, \mathrm{rt}$ & 72 \\
\hline $\mathbf{3 a}$ & $\mathrm{H}$ & $\mathrm{Me}$ & $\mathrm{MeI}, 3 \mathrm{~h},-20^{\circ} \mathrm{C}^{b}$ & 80 \\
\hline $\mathbf{3 b}$ & $\mathrm{H}$ & Et & $\mathrm{EtBr}, 3$ days, $-20^{\circ} \mathrm{C}^{b}$ & 45 \\
\hline $3 \mathbf{c}$ & $\mathrm{H}$ & $i$-Pr & $i$-PrI, 3 days, $-20^{\circ} \mathrm{C}^{b}$ & 41 \\
\hline 3d & $\mathrm{H}$ & All & AllBr, 1 day, $-20^{\circ} \mathrm{C}^{b}$ & 60 \\
\hline $\mathbf{3 e}$ & $\mathrm{H}$ & $\mathrm{Bz}$ & $\mathrm{BzBr}, 1$ day, $-20^{\circ} \mathrm{C}^{b}$ & 62 \\
\hline $4 \mathbf{a}$ & $\mathrm{Me}$ & Et & $\begin{array}{l}\mathrm{MeI},-78^{\circ} \mathrm{C}, 2 \mathrm{~h} ; \\
\mathrm{EtBr}, 1 \text { day, } 40^{\circ} \mathrm{C}\end{array}$ & 84 \\
\hline $4 b$ & Et & $\mathrm{Me}$ & $\begin{array}{l}\text { EtBr, }-78^{\circ} \mathrm{C}, 2 \mathrm{~h} \text {; } \\
\text { MeI } 12 \mathrm{~h}, \mathrm{rt}\end{array}$ & 91 \\
\hline $4 c$ & $\mathrm{Me}$ & $n$-Pr & $\begin{array}{l}\mathrm{MeI},-78^{\circ} \mathrm{C}, 2 \mathrm{~h} ; \\
\mathrm{PrBr}, 1 \text { day, } 40^{\circ} \mathrm{C}\end{array}$ & 76 \\
\hline 4d & $n-\operatorname{Pr}$ & $\mathrm{Me}$ & $\begin{array}{l}\mathrm{PrBr},-78^{\circ} \mathrm{C}, 2 \mathrm{~h} \\
\mathrm{MeI}, 12 \mathrm{~h}, \mathrm{rt}\end{array}$ & 89 \\
\hline
\end{tabular}

Some very interesting details have to be mentioned. In both experiments where MeI was added first (4a, 4c), a precipitate (presumably $\mathrm{PhNMeNLiBoc)}$ was formed. Be- cause of the insolubility of this intermediate, a second alkylation was carried out with the aid of slight heating (Table 1). Nevertheless, reactions took more time than in the case of $\mathbf{4 b}$ or $\mathbf{4 d}$ to complete. We have never noticed similar sedimentation in the course of the other reactions, despite the formation of PhNMeNLiBoc in two of them (once as product (2a) and once as an intermediate (1a)).

Several new methods for the selective hydrazine alkylation were developed. Use of a dianion for this purpose is reported for the first time. Also, the scope and limitations of applicability of this new method were demonstrated (Table 1). In summary, this new method can be easily applied in the systematic synthesis of hydrazine derivatives, in the synthesis of heterocycles, and even for analytical purposes (titration of BuLi).

Acknowledgment. This study was supported by grant No. 6706 from the Estonian Science Foundation. A. Bredihhin thanks the Herberdt Quandt foundation-Altana AG-for the fellowship.

Supporting Information Available: Experimental procedures and full spectroscopic data for all new compounds. This material is available free of charge via the Internet at http://pubs.acs.org.

\section{OL070026W}

(6) (a) Ragnarsson, U.; Grehn, L.; Koppel, J.; Loog, O.; Tsubrik, O.; Bredikhin, A.; Mäeorg, U.; Koppel, I. J. Org. Chem. 2005, 70, 59165921. (b) Bredikhin, A.; Tsubrik, O.; Sillard, R.; Mäeorg, U. Synlett 2005 1939-1941.

(7) (a) Wilkinson, D. E.; Thomas, B. E., IV; Limburg, D. C.; Holmes, A.; Sauer, H.; Ross, D. T.; Soni, R.; Chen, Y.; Guo, H.; Howorth, P.; Valentine, H.; Spicer, D.; Fuller, M.; Steiner, J. P.; Hamilton, G. S.; Wu, Y.-Q. Bioorg. Med. Chem. 2003, 11, 4815-4825. (b) Hemmerlin, C.; Cung, M. T.; Boussard, G. Tetrahedron Lett. 2001, 42, 5009-5012. 